\section{A) Check for updates}

Cite this: Dalton Trans., 2017, 46 , 11626

\title{
Synthesis and investigation of neptunium zirconium phosphate, a member of the NZP family: crystal structure, thermal behaviour and Mössbauer spectroscopy studies
}

\author{
D. M. Bykov, (D)*a,b R. J. M. Konings, (D) ${ }^{b}$ C. Apostolidis, ${ }^{b}$ A. Hen, ${ }^{b}$ E. Colineau, ${ }^{b}$ \\ T. Wiss ${ }^{\mathrm{b}}$ and P. Raison ${ }^{\mathrm{b}}$
}

\begin{abstract}
A new double neptunium zirconium phosphate of the type $M_{x} Z_{2}\left(P_{4}\right)_{3}(M=N p)$, crystallizing in the structure type $\mathrm{NaZr}_{2}\left(\mathrm{PO}_{4}\right)_{3}$ (NZP, NASICON), was synthesized by solid state reactions at high temperatures and characterized by X-ray diffraction, infrared spectroscopy and Mössbauer spectroscopy. The Rietveld refinement of the XRD pattern together with the analysis of the IR spectra of the sample confirmed the space group $P \overline{3} C$, the same as that for the lanthanide analogues $L_{0.33} Z r_{2}\left(P O_{4}\right)_{3}$. However, Mössbauer studies revealed the presence of neptunium in the two oxidation states +3 and +4 , indicating a twophase NZP system with different crystallographic environments of the neptunium atoms. The thermal behaviour of the sample was followed up to $1400{ }^{\circ} \mathrm{C}$ by thermogravimetric analysis.
\end{abstract}

Received 10th June 2017, Accepted 5th August 2017 DOI: $10.1039 / \mathrm{c} 7 \mathrm{dt} 02110 \mathrm{k}$ rsc.li/dalton
$\mathrm{ZrO}_{6}$ octahedra linked to three $\mathrm{PO}_{4}$ tetrahedra, which are aligned along the crystallographic $c$-direction of the unit cell, forming endless chains. ${ }^{14}$ Zirconium cations in the octahedral coordination (positions of the framework or L positions) can be substituted preferentially by cations of higher ionic charge and smaller radii in the range of $0.53-0.9 \AA^{15}$ Interstitial M1 positions, occupied by sodium, are located between the structure units of two $\mathrm{ZrO}_{6}$ octahedra and three $\mathrm{PO}_{4}$ tetrahedra. These positions are suitable for preferential substitution by larger cations of lower charge with radii in the range of 0.71-1.65 $\AA^{15}$ In sodium zirconium phosphate the interstitial M2 positions remain vacant but if the concentration of monovalent cations needed for the compensation of framework charges increases (for example, as a result of substitution of zirconium by trivalent cations), these sites will become occupied as well. However, such examples of filling the M2 positions are almost completely limited to the monovalent cations $\mathrm{Li}^{+}, \mathrm{Na}^{+}$and $\mathrm{K}^{+}$.

Isomorphic substitutions of cations in the interstitial and framework positions of the prototype compound $\mathrm{NaZr}_{2}\left(\mathrm{PO}_{4}\right)_{3}$ can be accompanied by the reduction of unit cell symmetry without major distortions of the framework structure units. Consequently, the NZP class of materials includes several space groups of related symmetry: $R \overline{3} c, R \overline{3}, R 3, R 32, P \overline{3} c$, $P \overline{3}^{1,16,17}$ In a number of cases monoclinic distortion of the lattice can lead to the appearance of a superstructure with space groups $C 2 / c$ or $C c{ }^{1}$

The inclusion of tri- and tetravalent cations of lanthanides and some of the actinides into the structure of NZP phosphates was reported in a number of papers. These elements

\footnotetext{
${ }^{a}$ Delft University of Technology, Faculty of Applied Sciences, Department of Radiation Science and Technology, Mekelweg 15, 2629 JB Delft, The Netherlands. E-mail:d.bykov@tudelft.nl

${ }^{b}$ European Commission, Joint Research Center (JRC) - Karlsruhe, P.O. Box 2340, D-76125 Karlsruhe, Germany
} 
can be incorporated into octahedral zirconium positions (L positions) or into interstitial M1 positions of the structure. Several studies have described the existence of limited solid solutions of the following types at room temperature: $\mathrm{KZr}_{2-x} \mathrm{U}_{x}\left(\mathrm{PO}_{4}\right)_{3}(0 \leq x \leq 0.2),{ }^{18} \mathrm{NaZr}_{2-x} \mathrm{~Np}_{x}\left(\mathrm{PO}_{4}\right)_{3}(0 \leq x \leq 0.6)$, $\mathrm{NaZr}_{2-x} \mathrm{Pu}_{x}\left(\mathrm{PO}_{4}\right)_{3}(0 \leq x \leq 0.2),{ }^{19,20} \mathrm{KZr}_{2-x} \mathrm{Pu}_{x}\left(\mathrm{PO}_{4}\right)_{3}(0 \leq x \leq$ $0.35, x=2) .{ }^{21}$ The actinide end members of these series, the phosphates $\mathrm{AM}_{2}\left(\mathrm{PO}_{4}\right)_{3}(\mathrm{M}=\mathrm{U}, \mathrm{A}=\mathrm{K}, \mathrm{Rb}$ and $\mathrm{M}=\mathrm{Np}, \mathrm{Pu}, \mathrm{A}=$ $\mathrm{Na}, \mathrm{K}, \mathrm{Rb}$ ), were shown to have polymorphic high-temperature NZP modifications (prepared at $1000{ }^{\circ} \mathrm{C}$ or above), while crystallizing in other structure types at lower temperatures. ${ }^{22-24}$ Solid solutions with trivalent rare earth elements at the L positions of the NZP structure with general formula $\mathrm{Na}_{1+x} \mathrm{R}_{x} \mathrm{Zr}_{2-x}\left(\mathrm{PO}_{4}\right)_{3}(\mathrm{R}=\mathrm{In}, \mathrm{Yb}, \mathrm{Er}, \mathrm{Y}, \mathrm{Dy}, \mathrm{Tb}, \mathrm{Gd}, \mathrm{Sm}, 0 \leq x \leq 1)$ are also known. ${ }^{11,25}$ It was shown that the limits of isomorphic substitutions of the REE ions in the framework positions strongly depended on the ionic radii of trivalent cations and rapidly decreased with increasing the latter. Thus, the maximum value of $x$ for $\mathrm{Sm}^{3+}$, the largest of the studied cations in the paper by Miyajima et al. ${ }^{11}\left(r\left(\mathrm{Sm}^{3+}\right)=0.958 \AA\right.$ $(\mathrm{CN}=6))$, was close to 0.2 .

In the above examples the $4 \mathrm{f}$ - and 5 f-elements occupy smaller zirconium positions of the structure. At the same time, the bigger M1 positions are expected to be more suitable for the larger cations of lanthanides and actinides in oxidation states +3 and +4 . Such examples are known: phosphates of trivalent lanthanides $\mathrm{Ln}_{0.33} \mathrm{Zr}_{2}\left(\mathrm{PO}_{4}\right)_{3}{ }^{7,16}$ and actinides $\mathrm{Am}_{0.33} \mathrm{Zr}_{2}\left(\mathrm{PO}_{4}\right)_{3},{ }^{26}$ and of tetravalent actinides $\mathrm{Th}_{0.25} \mathrm{Zr}_{2}\left(\mathrm{PO}_{4}\right)_{3},{ }^{27,28}$ $\mathrm{U}_{0.25} \mathrm{Zr}_{2}\left(\mathrm{PO}_{4}\right)_{3}{ }^{27}$ and $\mathrm{Pu}_{0.25} \mathrm{Zr}_{2}\left(\mathrm{PO}_{4}\right)_{3}{ }^{26}$ The isoformula phosphates with d-elements $\mathrm{Zr}_{0.25} \mathrm{Zr}_{2}\left(\mathrm{PO}_{4}\right)_{3}$ and $\mathrm{Hf}_{0.25} \mathrm{Hf}_{2}\left(\mathrm{PO}_{4}\right)_{4}{ }^{29-31}$ were also described. However, in the case of actinide compounds detailed crystal structure characterization is often lacking. Such studies are needed to understand the structural chemistry of actinides in this class of materials, proposed as alternative waste forms.

Neptunium is one of the long-lived components of nuclear waste and contributes substantially to the long term radiotoxicity of waste. The chemistry of the light actinides, to which neptunium belongs, is complex since these elements exhibit a transitional behaviour between the $5 \mathrm{~d}$ - and $4 \mathrm{f}$-metals. This is due to the proximity of the energies of $7 \mathrm{~s}^{-}, 6 \mathrm{~d}-$ and $5 \mathrm{f}$-shells which can easily contribute to the chemical bonding depending on the experimental conditions. This results in the possibility of existence of multiple oxidation states for these elements, sometimes simultaneously. Therefore, the question of oxidation state is important when characterizing compounds containing light actinides. With regard to the simple neptunium cations, both tri- and tetravalent oxidation states are expected to have reasonable stability, which is indicated by the slightly positive value of the reduction potential for $\mathrm{Np}^{4+} / \mathrm{Np}^{3+}$ pair $\left(E_{\mathrm{o}}=0.15 \mathrm{~V}\right) .^{32}$

The analysis of the literature data given above suggests several possibilities for the incorporation of tri- and tetravalent neptunium cations into the NZP structure: interstitial sodium positions $\mathrm{M} 1$ can accommodate both $\mathrm{Np}^{4+}$ and $\mathrm{Np}^{3+}$ cations to form theoretical compositions $\mathrm{Np}_{0.25} \mathrm{Zr}_{2}\left(\mathrm{PO}_{4}\right)_{3}$ and $\mathrm{Np}_{0.33} \mathrm{Zr}_{2}\left(\mathrm{PO}_{4}\right)_{3}$ with maximum occupancies of 0.25 and 0.33 , respectively, while framework zirconium positions would accommodate $\mathrm{Np}^{4+}$ and possibly $\mathrm{Np}^{3+}$ ions with the formation of solid solutions $\mathrm{NaZr}_{2-x} \mathrm{~Np}_{x}^{\mathrm{IV}}\left(\mathrm{PO}_{4}\right)_{3}$ and $\mathrm{Na}_{1+x} \mathrm{~Np}_{x}^{\mathrm{III}} \mathrm{Zr}_{2-x}\left(\mathrm{PO}_{4}\right)_{3}$. In the latter case the maximum value of $x$ is not known but is expected to be less than 0.2 , the limit established in ref. 11 and 25 for $\operatorname{Sm}\left(r\left(\mathrm{Sm}^{3+}\right)=0.958 \AA, r\left(\mathrm{~Np}^{3+}\right)=1.01 \AA\right)$.

In this paper we report the synthesis of a new double neptunium zirconium phosphate of the type $\mathrm{Np}_{x} \mathrm{Zr}_{2}\left(\mathrm{PO}_{4}\right)_{3}$, belonging to the NZP family, and the study of its crystal structure, thermal stability and the oxidation state of neptunium.

\section{Experimental}

\section{Synthesis}

All operations with isotope ${ }^{237} \mathrm{~Np}$ were carried out in nitrogenfilled gloveboxes, designed for working with radioactive substances, especially $\alpha$-emitters. The theoretical composition $\mathrm{Np}_{0.25} \mathrm{Zr}_{2}\left(\mathrm{PO}_{4}\right)_{3}$ was targeted, since previously published research indicated the stabilization of the tetravalent state of neptunium in the NZP phosphates. Therefore, neptunium dioxide $\mathrm{NpO}_{2}$ was taken for the synthesis. Several methods were used for the preparation of the neptunium zirconium phosphate.

In the first method, we used solutions of zirconium oxychloride $\left(\mathrm{ZrOCl}_{2}\right)(1.385 \mathrm{M})$, phosphoric acid $\left(\mathrm{H}_{3} \mathrm{PO}_{4}\right)(1.483 \mathrm{M})$ and a powder of neptunium dioxide $\left(\mathrm{NpO}_{2}\right)$. Stoichiometric amounts of these materials were mixed together in a glass beaker and carefully dried on a sand bath $\left(T \approx 50-60{ }^{\circ} \mathrm{C}\right)$ to prevent possible change of the oxidation state of neptunium. The thus obtained precursor powder of light-yellow colour was then ground in an agate mortar with a small amount of isopropyl alcohol. Heat treatments were performed in a furnace under a pure argon atmosphere. After the first heat treatment at $600{ }^{\circ} \mathrm{C}$ for $24 \mathrm{~h}$, the powder turned in colour to dark-grey, almost black. It was ground again before the next heating at $800 \mathrm{C}$ for $24 \mathrm{~h}$. The sample became black-green after this temperature. This step was followed by XRD analysis. The scheme of the synthesis is summarized in Fig. 1.

The second method of synthesis was via solid state reagents. Stoichiometric amounts of the $\mathrm{NpO}_{2}$ powder, $\mathrm{ZrOCl}_{2} \cdot 8 \mathrm{H}_{2} \mathrm{O}$ and $\left(\mathrm{NH}_{4}\right)_{2} \mathrm{HPO}_{4}$ in solid forms were placed in an agate-lined stainless steel jar with agate grinding bodies and ground for 23 hours using a vibrational mill RETSCH MM301 at a frequency of $20 \mathrm{~s}^{-1}$. The precursor (yellow colour) was then split into two parts, which were heated under different atmospheres: argon or air (oxygen). The temperature regimes applied for the heat treatments were in both cases $600{ }^{\circ} \mathrm{C}, 72 \mathrm{~h}$ and $800{ }^{\circ} \mathrm{C}, 24 \mathrm{~h}$. After the first heat treatment at $600{ }^{\circ} \mathrm{C}$ the sample synthesized in argon was grey in colour, which remained as such after further heating at $800{ }^{\circ} \mathrm{C}$. In contrast, the sample prepared in air almost did not change its colour (light-yellow) after both heating steps.

It should be noted that both of these routes represent schemes for the synthesis of starting precursor powders 


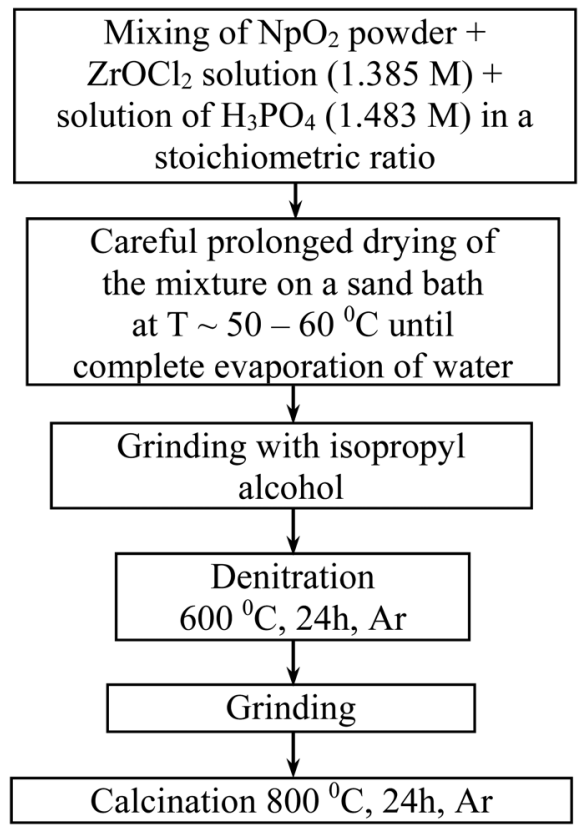

Fig. 1 The scheme of synthesis of neptunium zirconium phosphate with the NZP structure.

needed for obtaining a final ceramic nuclear waste form. The fabrication of such waste forms would require additional steps to produce monolithic materials having acceptable durability. These methods include hot uniaxial pressing (HUP), hot isostatic pressing (HIP), pressing followed by sintering, etc. ${ }^{33}$

\section{X-ray diffraction analysis}

XRD patterns at room temperature were measured using a Seifert 3000 diffractometer, $\mathrm{CuK} \alpha_{1,2}$ radiation, a scintillation detector, Bragg-Brentano geometry, and $\theta-\theta$ configuration. The diffraction pattern for the Rietveld analysis was collected with a Bruker D8 diffractometer operated in a Bragg-Brentano configuration with a curved Ge (111) monochromator having a ceramic $\mathrm{Cu}$ tube and a Vantec position sensitive detector. The measurements were performed at $40 \mathrm{kV}$ and $40 \mathrm{~mA}$. In both machines the goniometers were mounted directly inside the gloveboxes.

The XRD samples were prepared by depositing an analysed powder mixed with an epoxy glue on the surface of a specially designed plastic sample holder. This technique allowed avoiding spreading of contamination and simplified further the handling of waste.

Phase analysis was performed using the databases ICSD and PDF4 and the crystallographic software "Match!" (version 1.10). Rietveld analysis was carried out using the FullProf software package. ${ }^{34}$ Structure visualization was realized with the computer program VESTA. ${ }^{35}$

\section{SEM analysis}

The SEM-EDX analysis was performed on a FEI (Philips) XL 40 instrument with $3 \mathrm{~nm}$ resolution using an accelerating voltage of $25 \mathrm{kV}$. The samples were measured without coating. The detection and quantitative calculations were based on the measurements of the intensities of $\mathrm{M}_{\alpha}$-lines of neptunium, $\mathrm{L}_{\alpha}$-lines of zirconium and $\mathrm{K}_{\alpha}$-lines of phosphorus. Oxygen was not analysed. The EDX spectra were quantified by a standardless method using the PAP correction. ${ }^{36}$

\section{DTA/TG analysis}

Differential thermal analysis (DTA) and thermogravimetry (TG) were carried out using Netzsch STA 409 C/CD apparatus. Samples were placed in alundum crucibles and heated in the temperature range from room temperature to $1400{ }^{\circ} \mathrm{C}$. The mass of the analysed powders did not exceed $40 \mathrm{mg}$. Measurements were performed under a pure nitrogen atmo-

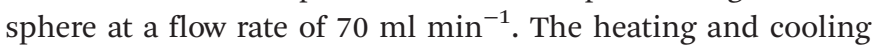
rates were $7 \mathrm{~K} \mathrm{~min}^{-1}$.

\section{Infrared spectroscopy}

The IR spectrum of the sample at room temperature was obtained using a PerkinElmer 2000 Fourier transform infrared (FT-IR) spectrophotometer with a resolution of $1 \mathrm{~cm}^{-1}$. The powder was diluted in $\mathrm{KBr}$ and pressed into pellets for the measurements.

\section{Mössbauer spectroscopy}

The ${ }^{237} \mathrm{~Np}$ Mössbauer spectrum was recorded in a transmission geometry, using the sinusoidal drive motion of a $\sim 100 \mathrm{mCi}{ }^{241} \mathrm{Am}$ metal source. The maximum velocity scale of the spectrometer $\left(125 \mathrm{~mm} \mathrm{~s}^{-1}\right)$ was determined with respect to the $\mathrm{NpAl}_{2}$ calibration standard $\left(B_{\mathrm{hf}}=330 \mathrm{~T}\right.$ at $\left.4.2 \mathrm{~K}\right)$. Both the source and the absorber were kept at a constant temperature of $4.2 \mathrm{~K}$ using a liquid helium cryostat. The absorber was prepared by encapsulating $\sim 150 \mathrm{mg}$ of a fine powdered sample of neptunium zirconium phosphate in three concentric aluminium containers.

\section{Results and discussion}

\section{XRD characterization}

Both synthetic routes resulted in the formation of products crystallizing in the structure type $\mathrm{NaZr}_{2}\left(\mathrm{PO}_{4}\right)_{3}$ but only the sample prepared by method 1 (Fig. 1) gave a powder with enough crystallinity to perform the Rietveld analysis after $800{ }^{\circ} \mathrm{C}$ (Fig. 2a).

Heating of the precursor powder prepared by method 2 under an $\mathrm{Ar}$ or $\mathrm{O}_{2}$ atmosphere gave powders of grey and lightyellow colours, respectively. Despite the difference in colour, XRD measurements performed after successive heat treatments up to $800{ }^{\circ} \mathrm{C}$ both gave practically the same patterns corresponding to $\mathrm{NpO}_{2}$ (Fig. 2b), except that the sample obtained in oxygen also showed small reflections belonging to other phases. Both samples were further heated at $900{ }^{\circ} \mathrm{C}$ for $25 \mathrm{~h}(\mathrm{Ar})$ and $15 \mathrm{~h}\left(\mathrm{O}_{2}\right)$. Only treatment in argon resulted in the formation of a powder with the NZP structure (Fig. 2d). At the same time, the diffraction peaks were broad and of rather 


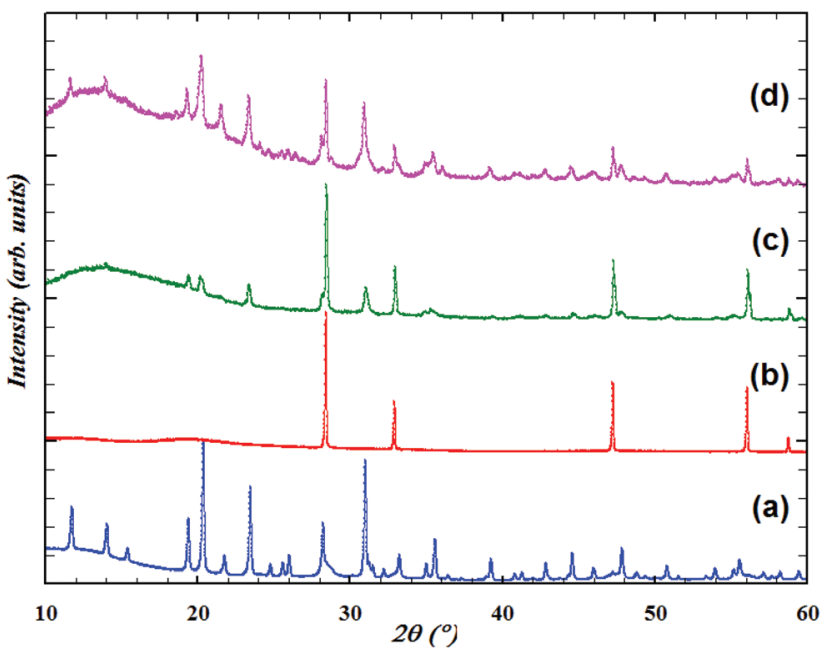

Fig. 2 Normalized X-ray powder diffraction patterns of neptunium zirconium phosphate obtained by (a) method 1 at $800{ }^{\circ} \mathrm{C}$; (b) method 2 in argon at $800{ }^{\circ} \mathrm{C}$ (only reflections of $\mathrm{NpO}_{2}$ are present); (c) method 2 in argon at $874{ }^{\circ} \mathrm{C}, 25 \mathrm{~h}$ (NZP phase starts to form but $\mathrm{NpO}_{2}$ is still the main phase); (d) method 2 in argon at $900{ }^{\circ} \mathrm{C}$ (the main phases are NZP, $\mathrm{NpO}_{2}$ and $\left.\mathrm{ZrP}_{2} \mathrm{O}_{7}\right)$.

low intensity, which indicated the low crystallinity of the material. In addition, the sample also contained significant amounts of $\mathrm{ZrP}_{2} \mathrm{O}_{7}$ and $\mathrm{NpO}_{2}$ admixtures. Heating of the powder, prepared at $600{ }^{\circ} \mathrm{C}$ in argon, at $874{ }^{\circ} \mathrm{C}$ gave an intermediate XRD pattern (Fig. 2c), which means that $\mathrm{NpO}_{2}$ powder started to react around this temperature.

Comparison of the results of the two methods indicates that the history of the reactants (synthesis route, annealing temperature etc.) needs to be taken into account during the solid state synthesis procedure. Since method 1 resulted in the most crystalline material, only this sample was used for further characterization.

\section{Infrared (IR) spectroscopy}

Factor group analysis of vibrations of the orthophosphate ion in compounds with the space group $R \overline{3} c$ was carried out by Kurazhkovskaya et $a l^{27}$ For this space group one can expect one $\nu_{1}$ band, two $\nu_{2}$ bands, and five bands of each of the $\nu_{3}$ and $\nu_{4}$ vibrations. Here the symbols $\nu_{1}, \nu_{2}, \nu_{3}$ and $\nu_{4}$ denote symmetric stretching, symmetric bending, asymmetric stretching and asymmetric bending $\mathrm{P}-\mathrm{O}$ vibrations, respectively. In the spectra of double zirconium phosphates with alkali elements five bands of asymmetric stretching vibrations overlap, and in the spectra of $\mathrm{NaZr}_{2}\left(\mathrm{PO}_{4}\right)_{3}$ they appear as one broad band with a maximum at about $1045 \mathrm{~cm}^{-1}$ and a weak high-frequency band $\left(1200 \mathrm{~cm}^{-1}\right)$ due to the contribution of the electron density of $\mathrm{Zr}$ to the $\mathrm{P}-\mathrm{O}$ bond. ${ }^{27}$ However, with decreasing symmetry (from space group $R \overline{3} c$ to space groups $R \overline{3}$ and $P \overline{3} c$ ) these bands split and the number of possible bands increases. ${ }^{27}$ For the phosphates crystallizing in NZP type, this symmetry change corresponds to the compositional change from $\mathrm{AM}_{2}\left(\mathrm{PO}_{4}\right)_{3}$ (sp. gr. $R \overline{3} c$ ) to $\mathrm{B}_{0.5} \mathrm{Zr}_{2}\left(\mathrm{PO}_{4}\right)_{3}$ (sp. gr. $R \overline{3}$ ) and to $\mathrm{R}_{0.33} \mathrm{Zr}_{2}\left(\mathrm{PO}_{4}\right)_{3}$ (sp. gr. $P \overline{3} c$ ) (A, B, and $\mathrm{R}$ stand for mono-, di- and trivalent cations). The reduction of symmetry in phosphates $\mathrm{Ln}_{0.33} \mathrm{Zr}_{2}\left(\mathrm{PO}_{4}\right)_{3}$ with the appearance of additional lines in the IR spectra was explained by the ordering of Ln atoms at the M1 positions of the structure. ${ }^{16}$ It should be also noted that the IR spectra of phosphates $\mathrm{M}_{0.25} \mathrm{Zr}_{2}\left(\mathrm{PO}_{4}\right)_{3}(\mathrm{M}=\mathrm{Th}, \mathrm{U})$, which were described in the same paper of Kurazhkovskaya et al., ${ }^{27}$ resembled much more the spectrum of the parent compound $\mathrm{NaZr}_{2}\left(\mathrm{PO}_{4}\right)_{3}$, which led to the conclusion that the actinide atoms were distributed over M1 sites statistically and the symmetry $R \overline{3} c$ remained.

The IR spectrum of the $\mathrm{Np}$ phase, synthesized in the present work using method 1, is shown in Fig. 3. It is identical to the spectra of the rare earth phases with the space group $R \overline{3} c{ }^{27,37}$ The IR bands observed in the region from 500 to $640 \mathrm{~cm}^{-1}$ are assigned to the asymmetrical bending $\nu_{4}$ vibrations of the $\mathrm{PO}_{4}$ units, bands from 920 to $980 \mathrm{~cm}^{-1}$ - to symmetrical stretching $\nu_{1}$ vibrations, and from about 1000 to $1280 \mathrm{~cm}^{-1}$ - to asymmetrical stretching $\nu_{3}$ vibrations. As in the case of lanthanide zirconium phosphates, the position of the weak high-frequency band of asymmetric vibrations at $1280 \mathrm{~cm}^{-1}$, which is generally not characteristic of phosphates, is explained by the contribution of a part of the electronic density of small and highly charged polarizing zirconium cations to the $\mathrm{P}-\mathrm{O}$ bond..$^{27,38}$ The spectrum is also characterized by the presence of molecular water - bands at 3435 and $1631 \mathrm{~cm}^{-1}$ - which could be a result of absorption of some moisture by the sample during storage, or could be introduced with potassium bromide used for the preparation of pellets for the IR measurements. The band at $2662 \mathrm{~cm}^{-1}$ is assigned to the vibrations of $\mathrm{OH}$-groups in the acidic $\mathrm{POH}$-ions, which is possibly due to the fact that phosphoric acid $\left(\mathrm{H}_{3} \mathrm{PO}_{4}\right)$ was used for the synthesis.

The analogy of the IR spectrum of the neptunium phase, obtained in the present study, with the spectra of double phos-

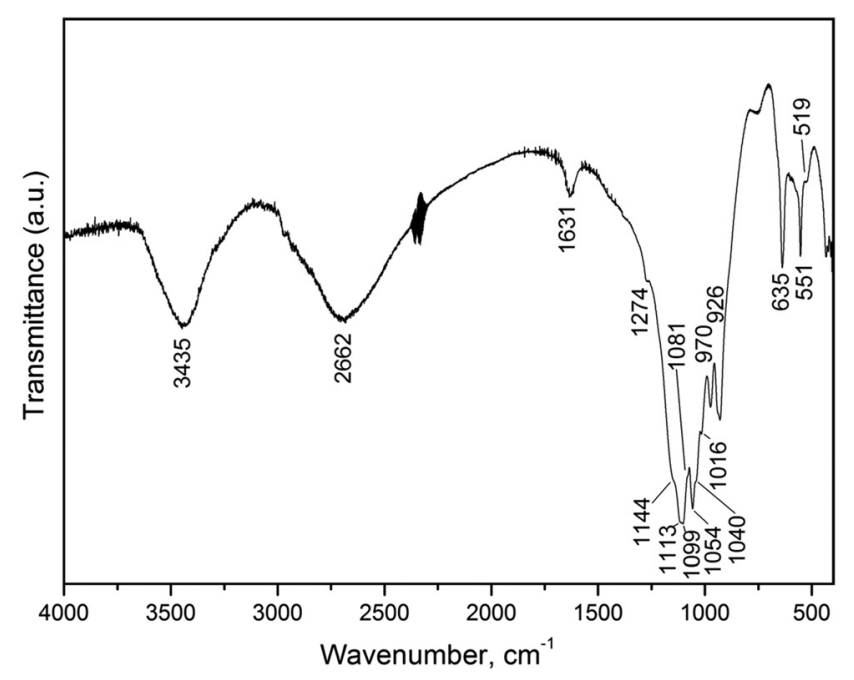

Fig. 3 Infrared spectrum of the studied neptunium zirconium phosphate with NZP structure. 
phates $\operatorname{Ln}_{0.33} \mathrm{Zr}_{2}\left(\mathrm{PO}_{4}\right)_{3}$ indicates that the neptunium compound possesses the same symmetry as the lanthanide zirconium phosphates, and regarding the oxidation state points to the conclusion that neptunium is present in the trivalent state.

In order to obtain information on the valence state of neptunium in the sample, we performed Mössbauer spectroscopy, a method which provides direct indication of the oxidation state.

\section{Mössbauer spectroscopy}

For the investigation, we used a sample prepared by method 1 at $800{ }^{\circ} \mathrm{C}$ (see the Experimental section). The Mössbauer spectrum of the neptunium sample is shown in Fig. 4. Taking into account the IR data (a possible trivalent oxidation state of neptunium), the measured spectrum was fitted with three sets of hyperfine parameters, one for the main hexagonal phase, containing neptunium in the oxidation state +3 , the second set for the hexagonal phase in which neptunium has the oxidation state +4 , and the last set for a cubic $\mathrm{NpO}_{2}$ (which was also identified from the X-ray diffraction pattern). The values of isomer shifts and parameters of quadrupole interaction for the spectra of the main phase, the secondary phase and $\mathrm{NpO}_{2}$ are shown in Table 1. Estimation of the relative concentrations from the fitted data yields roughly (in mol\% Np) $77 \%$ for the main hexagonal phase, $14 \%$ for the secondary hexagonal phase and $9 \%$ for the cubic $\mathrm{NpO}_{2}$. It should be noted that

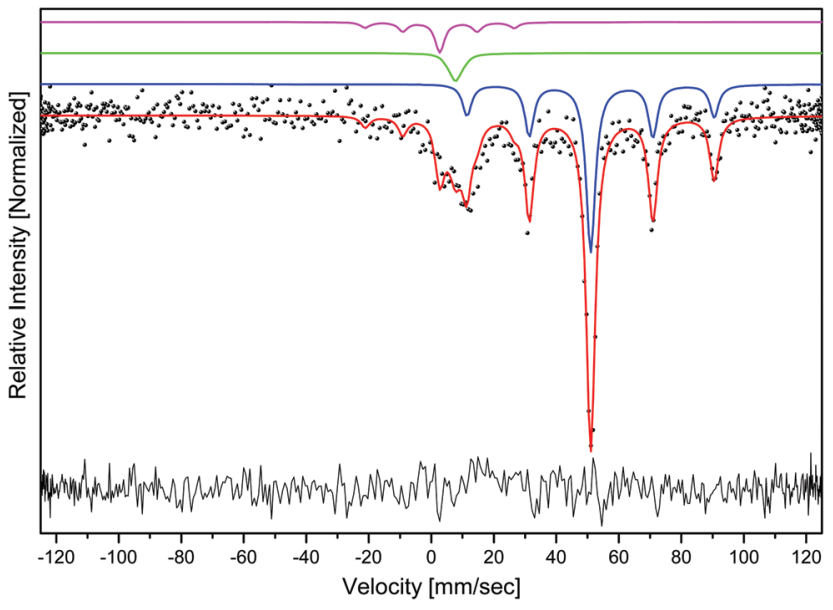

Fig. 4 Mössbauer spectrum of the double neptunium zirconium phosphate. Dots represent the experimental data, red line - the fitted curve, blue line - the contribution from the main NZP phase with $\mathrm{Np}^{3+}(\sim 77 \%)$, green line - the $\mathrm{NpO}_{2}$ impurity ( $9 \%$ ), purple line - the secondary phase containing $\mathrm{Np}^{4+}(\sim 14 \%)$.

Table 1 Parameters of the Mössbauer spectrum of the neptunium zirconium phosphate powder

\begin{tabular}{lcll}
\hline & ISO, $\mathrm{mm} \mathrm{s}^{-1}$ & QUA, $\mathrm{mm} \mathrm{s}^{-1}$ & Relative intensity \\
\hline Main phase & $51.04(5)$ & $66.1(2)$ & $77 \%$ \\
Secondary phase & $2.7(3)$ & $39.7(1.4)$ & $14 \%$ \\
$\mathrm{NpO}_{2}$ phase & $7.75(0)$ & $5.1(0)$ & $9 \%$
\end{tabular}

these percentages are based on the area integration of the different sub-spectra and might vary, especially due to the relatively low measured signal, high background and the fact that there is an excess of material that is not visible (no Np in it) and might be caused by a non-homogeneous mixture of the different phases within the sample.

Since both $\mathrm{Np}_{0.25} \mathrm{Zr}_{2}\left(\mathrm{PO}_{4}\right)_{3}$ and $\mathrm{Np}_{0.33} \mathrm{Zr}_{2}\left(\mathrm{PO}_{4}\right)_{3}$ can exist in theory and would differ only in their space groups $(R \overline{3} c v s . P \overline{3} c$, based on the analogy found in the literature), we can assign the hexagonal phases with tetra- and trivalent neptunium, observed in the Mössbauer measurements, to these two theoretical formulas.

Furthermore, taking into account that the targeted stoichiometry was $\mathrm{Np}_{0.25} \mathrm{Zr}_{2}\left(\mathrm{PO}_{4}\right)_{3}$, the obtained molar percentages would correspond to (wt\%) $\sim 62 \%$ of $\mathrm{Np}_{0.33} \mathrm{Zr}_{2}\left(\mathrm{PO}_{4}\right)_{3}, \sim 1 \%$ of $\mathrm{NpO}_{2}$ and $\sim 15 \%$ of $\mathrm{Np}_{0.25} \mathrm{Zr}_{2}\left(\mathrm{PO}_{4}\right)_{3}$. To compensate for the difference in stoichiometry one also needs to consider the presence of $\sim 22 \%$ of an impurity phase, which does not contain any neptunium and binds the excess of zirconium and phosphorus. This impurity might be, for instance, a compound with a bulk chemical composition, $\mathrm{Zr}_{2} \mathrm{P}_{2} \mathrm{O}_{9}$, although only small traces of crystalline $\mathrm{ZrP}_{2} \mathrm{O}_{7}$ and $\mathrm{ZrO}_{2}$ could be identified from the XRD pattern. At the same time, the presence of an amorphous component could also be seen at the diffractograms, appearing as an increased background with a complex shape, especially at lower angles. The exact composition of all impurity phases in this case is difficult to identify. Important is, however, that the XRD data do not contradict the conclusion of the presence of $\sim 22 \%$ of Np-free phase, drawn from the results of Mössbauer spectroscopy.

\section{Rietveld analysis}

Phase analysis of the sample revealed the presence of four crystalline phases: a major component with the structure of NZP and admixtures of $\mathrm{ZrP}_{2} \mathrm{O}_{7}, \mathrm{NpO}_{2}$ and $\mathrm{ZrO}_{2}$. The presence of several additional reflections, also observed for the double lanthanide zirconium phosphates, ${ }^{16}$ but not for the sodium zirconium phosphate, clearly indicates the reduction of symmetry compared to the prototype compound $\mathrm{NaZr}_{2}\left(\mathrm{PO}_{4}\right)_{3}$ (from the space group $R \overline{3} c$ to the space group $P \overline{3} c$ ). Taking this into account and also the fact that neptunium was found to be mainly trivalent, we used the structure of $\mathrm{Eu}_{0.33} \mathrm{Zr}_{2}\left(\mathrm{PO}_{4}\right)_{3}{ }^{16}$ as the starting model for crystal structure refinement, suggesting the chemical formula $\mathrm{Np}_{0.33} \mathrm{Zr}_{2}\left(\mathrm{PO}_{4}\right)_{3}$ for the studied phosphate.

The model was refined by the Rietveld method using the FullProf Suite Program (2.05). Additional phases were also introduced during the refinement procedure, but only their profiles were refined using the LeBail algorithm. The background was modelled by a set of manually selected consecutive points with adjustable intensities. Soft distance constraints were applied to $\mathrm{P}-\mathrm{O}$ distances of the main phase in order to keep them within reasonable values found for phosphate minerals. $^{39}$ The progress of the crystallographic refinement was monitored using the values of reliability factors ( $R$-factors). The refinement rounds continued until $R$-factors reached a 
Table 2 Crystallographic data and the results of crystal structure refinement of neptunium zirconium phosphate

\begin{tabular}{ll}
\hline Chemical formula sum & $\mathrm{Np}_{0.29} \mathrm{Zr}_{2}\left(\mathrm{PO}_{4}\right)_{3}$ \\
Structure model & $\mathrm{Eu}_{0.33} \mathrm{Zr}_{2}\left(\mathrm{PO}_{4}\right)_{3}$ \\
Crystal system & $\mathrm{Hexagonal}$ \\
Space group & $P \overline{3} c(165)$ \\
$a, \AA$ & $8.755(1)$ \\
$b, \AA$ & $8.755(1)$ \\
$c, \AA$ & $23.101(3)$ \\
$V, \AA$ & $1533.6(1)$ \\
$Z$ & 6 \\
$2 \theta$-range $\left({ }^{\circ}\right)$ & $5-150$ \\
Number of reflections & 1088 \\
General number of points & 16915 \\
Number of fitted parameters & 121 \\
$R_{\mathrm{B}}, \%$ & 2.31 \\
$R_{\mathrm{wp}}, \%$ & 3.17 \\
$R_{\mathrm{f}}=2.06 \%, R_{\mathrm{p}}=2.31 \%, R_{\text {exp }}=1.69 \%, \chi^{2}=3.51$. &
\end{tabular}

Table 3 Refined atomic positions of neptunium zirconium phosphate

\begin{tabular}{lllllll}
\hline Atom & Site & $x$ & $y$ & $z$ & $U, \AA^{2}$ & Occ. \\
\hline Np1 & 2b & 0 & 0 & 0 & 0.0501 & 0.143 \\
Zr1 & 4c & 0 & 0 & $0.15136(5)$ & 0.0150 & 0.333 \\
Zr2 & 4d & 0.6667 & 0.3333 & $0.47299(7)$ & 0.0086 & 0.333 \\
Zr3 & 4d & 0.3333 & 0.6667 & $0.81197(7)$ & 0.0180 & 0.333 \\
P1 & 6f & $0.2849(2)$ & 0 & 0.25 & 0.0248 & 0.5 \\
P2 & 12g & $0.9466(1)$ & $0.3262(2)$ & $0.58042(5)$ & 0.0219 & 1.0 \\
O1 & 12g & $0.1582(6)$ & $-0.0427(9)$ & $0.1987(2)$ & 0.0417 & 1.0 \\
O2 & 12g & $0.8243(8)$ & $0.292(1)$ & $0.5278(2)$ & 0.0417 & 1.0 \\
O3 & $12 \mathrm{~g}$ & $0.5370(7)$ & $0.698(1)$ & $0.8638(1)$ & 0.0417 & 1.0 \\
O4 & $12 \mathrm{~g}$ & $0.2012(6)$ & $0.1608(7)$ & $0.0946(2)$ & 0.0417 & 1.0 \\
O5 & $12 \mathrm{~g}$ & $0.8760(5)$ & $0.5002(6)$ & $0.4285(3)$ & 0.0417 & 1.0 \\
O6 & $12 \mathrm{~g}$ & $0.5304(4)$ & $0.8352(5)$ & $0.7522(2)$ & 0.0417 & 1.0
\end{tabular}

stable minimum value with no further improvements. At the last stages, values of atomic displacement parameters were refined for neptunium, zirconium, phosphorus and oxygen atoms. Finally, the occupancy of the neptunium position was refined. Releasing this parameter during the refinement improved the fitting and was accompanied by a slight decrease of $R$-factors. The refinement converged at $R_{\mathrm{B}}=2.5, R_{\mathrm{f}}=2.06$ for the main phase, $R_{\mathrm{p}}=2.31, R_{\mathrm{wp}}=3.17$ (not corrected for background) and $\chi^{2}=3.51$. Values of the unit cell parameters and details of the pattern fitting can be found in Table 2. The refined structural parameters are given in Table 3. Observed and calculated XRD patterns and the structure fragment are shown in Fig. 5 and 6, respectively.

The lower value of the occupancy factor for neptunium in comparison with the one expected on the basis of the theoretical composition $\mathrm{Np}_{0.33} \mathrm{Zr}_{2}\left(\mathrm{PO}_{4}\right)_{3}$ (0.143 vs. 0.1667, Table 3) corresponds to the empirical formula $\mathrm{Np}_{0.29} \mathrm{Zr}_{2}\left(\mathrm{PO}_{4}\right)_{3}$. This is in good agreement with the results of Mössbauer spectroscopy for the presence of two phases containing neptunium in the oxidation state $+3(77 \mathrm{~mol} \%)$ and $+4(14 \mathrm{~mol} \%)$, giving the same gross formula $\mathrm{Np}_{0.29} \mathrm{Zr}_{2}\left(\mathrm{PO}_{4}\right)_{3}$. In this case, the X-ray diffraction provides an averaged pattern for the mixture of two NZP phases with different oxidation states of neptunium. Introducing the model of the $\mathrm{Np}_{0.25} \mathrm{Zr}_{2}\left(\mathrm{PO}_{4}\right)_{3}$ phase into the

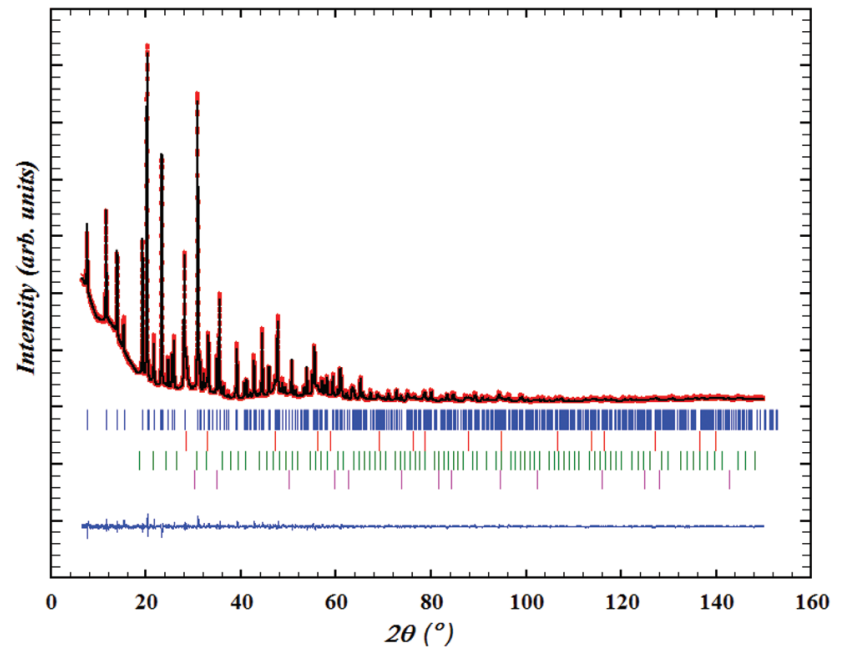

Fig. 5 Observed and calculated powder X-ray diffraction patterns of the double neptunium zirconium phosphate, sp. gr. $P \overline{3} c$ (no. 165). The difference pattern is shown at the bottom of the picture. Vertical bars indicate the calculated positions of the Bragg reflections of the main phase and the impurities of cubic $\mathrm{NpO}_{2}$ (sp. gr. $\mathrm{Fm} \overline{3} m$ ), $\mathrm{ZrP}_{2} \mathrm{O}_{7}$ (sp. gr. $\mathrm{Pa} \overline{3}$ ) and $\mathrm{ZrO}_{2}$ (sp. gr. $\left.\mathrm{Fm} \overline{3} \mathrm{~m}\right)$.

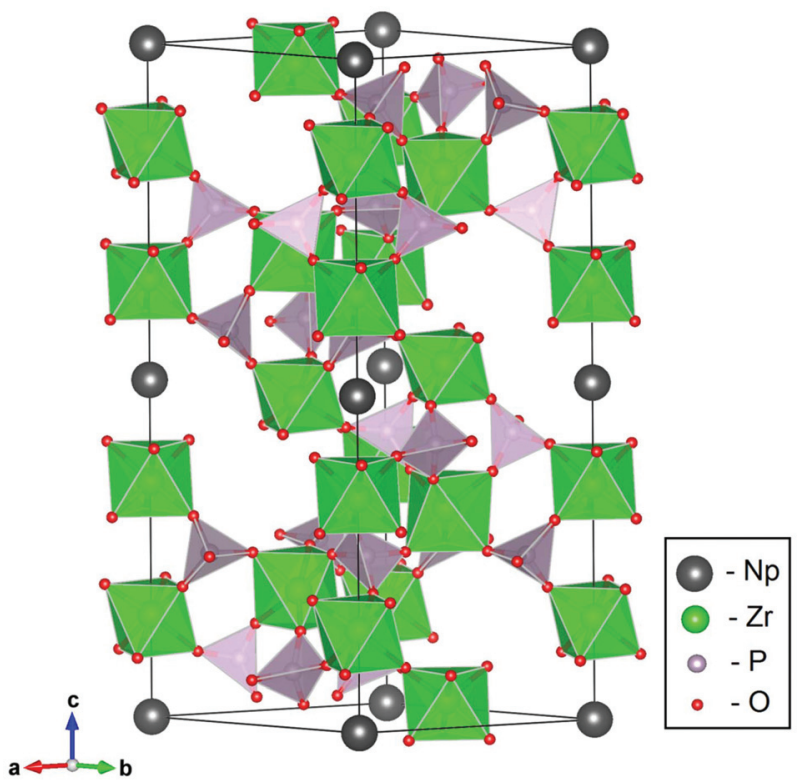

Fig. 6 Structure fragment of neptunium zirconium phosphate.

refinement, alongside $\mathrm{Np}_{0.33} \mathrm{Zr}_{2}\left(\mathrm{PO}_{4}\right)_{3}$, did not improve the fit and the $R$-factors. This is not surprising, since the anticipated symmetry and diffraction pattern would be very similar to that of $\mathrm{Np}_{0.33} \mathrm{Zr}_{2}\left(\mathrm{PO}_{4}\right)_{3}$, leading to overlapping of the diffraction patterns.

The relatively high value of $\chi$-criteria can be explained by the presence of an amorphous component, which does not give reflections at the XRD pattern (in agreement with the Mössbauer data) and could also be due to imperfection of the 
structure model (the presence of $\mathrm{Np}_{0.25} \mathrm{Zr}_{2}\left(\mathrm{PO}_{4}\right)_{3}$ is not taken into account during the refinement).

\section{SEM/EDX-analysis}

The sample is characterized by a uniform microstructure (Fig. 7). The powder consists of agglomerations of particles of bigger and smaller sizes, some of them reaching a few tenths of microns. The EDX analysis showed that the sample contains regions, the chemical composition of which oscillates around the expected $\mathrm{Np}: \mathrm{Zr}$ ratio in the targeted material. At the same time, some minor regions were found that were either enriched or depleted in neptunium (Fig. 7). This is also in agreement with the presence of $\mathrm{NpO}_{2}$ and $\mathrm{Zr}_{2} \mathrm{P}_{2} \mathrm{O}_{9}$ phases, discussed earlier in the section on Mössbauer spectroscopy. EDX analyses of randomly scanned areas, excluding Np-depleted and $\mathrm{Np}$-enriched regions, give the average $\mathrm{Np}: \mathrm{Zr}$ ratio of 1:8.9 corresponding to the mean chemical composition $\mathrm{Np}_{0.23} \mathrm{Zr}_{2}\left(\mathrm{PO}_{4}\right)_{3}$ (NZP-region in Fig. 7). Among these areas there were also regions corresponding to an average formula $\mathrm{Np}_{0.28} \mathrm{Zr}_{2}\left(\mathrm{PO}_{4}\right)_{3}$, which is closer to the value found by the Rietveld analysis. However, the difference is likely to be attributed to other factors during sample preparation and measurement, rather than the actual difference in chemical composition. These factors are, for example, inhomogeneity of the sample, unpolished surface, porosity of the powder and others.

\section{Thermal behaviour}

Fig. 8 shows the TG/DTA curves of the studied neptunium zirconium phosphate recorded from room temperature up to $1400{ }^{\circ} \mathrm{C}$. The appearance of two small exothermal peaks on the DTA curve at $\sim 970{ }^{\circ} \mathrm{C}$ and $1080{ }^{\circ} \mathrm{C}$, shown by arrows in Fig. 8 , is accompanied by a small decrease of mass at the TG curve and is attributed to the decomposition of the sample, in agreement with Alami Talbi et al. ${ }^{7}$ and Bykov et al. ${ }^{40}$

In addition to the TG/DTA analysis, the sample synthesized at $800{ }^{\circ} \mathrm{C}$ in argon was further heated at $856{ }^{\circ} \mathrm{C}(20 \mathrm{~h}), 900{ }^{\circ} \mathrm{C}$ $(25 \mathrm{~h})$ and $1000{ }^{\circ} \mathrm{C}(2 \mathrm{~h})$ in argon and at $805{ }^{\circ} \mathrm{C}(15 \mathrm{~h})$ and $900{ }^{\circ} \mathrm{C}(20 \mathrm{~h})$ in a pure oxygen atmosphere in order to study its

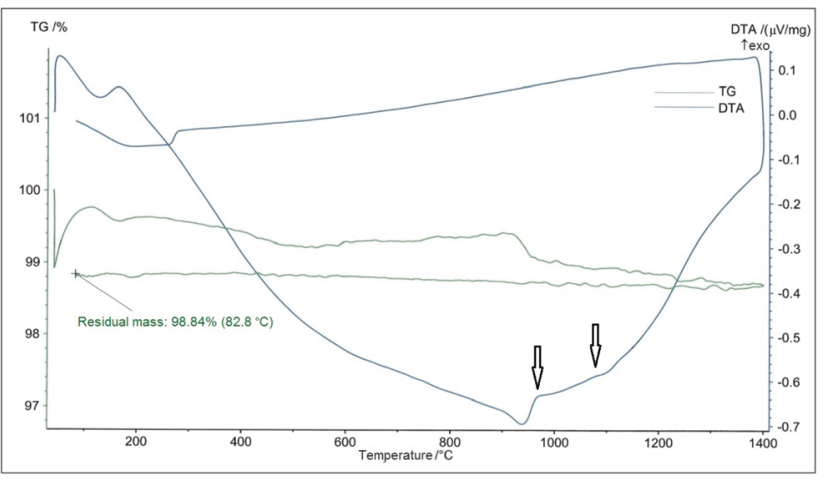

Fig. 8 TG/DTA curves of the studied neptunium zirconium phosphate. Arrows indicate peaks attributed to the decomposition of the sample.

thermal stability. In both cases, increasing the temperature leads to the increase of the content of the secondary phase of zirconium pyrophosphate, $\mathrm{ZrP}_{2} \mathrm{O}_{7}$. This process occurs faster when oxygen is used as an atmosphere. In this case already after $900{ }^{\circ} \mathrm{C}$ zirconium pyrophosphate becomes the major phase, whereas in the case of argon most of the powder after $900{ }^{\circ} \mathrm{C}$ still consists of the NZP phase and only after $1000{ }^{\circ} \mathrm{C}$ does zirconium pyrophosphate start to dominate. Unidentified smaller peaks were also observed at the XRD patterns obtained after treatment of the powder at $900{ }^{\circ} \mathrm{C}$ and $1000{ }^{\circ} \mathrm{C}$ in argon and after $805{ }^{\circ} \mathrm{C}$ and $900{ }^{\circ} \mathrm{C}$ in oxygen.

Thus, both data for thermal analysis and X-ray diffraction lead to the conclusion that the studied neptunium zirconium phosphate starts to decompose at temperatures of around $850{ }^{\circ} \mathrm{C}$. This value is close to the decomposition temperature of the phosphates of zirconium with lanthanides $\operatorname{Ln}_{0.33} \mathrm{Zr}_{2}\left(\mathrm{PO}_{4}\right)_{3}{ }^{7,40-42}$

The diffractograms of all samples heated in argon contained reflections consistent with the space group $P \overline{3} c$. This allowed us to perform the LeBail fit of the diffraction data and to calculate the unit cell parameters (Table 4). It can be seen that there is a gradual decrease of the parameters $a, c$ and of the volume $V$ with the increase of the temperature of the heat
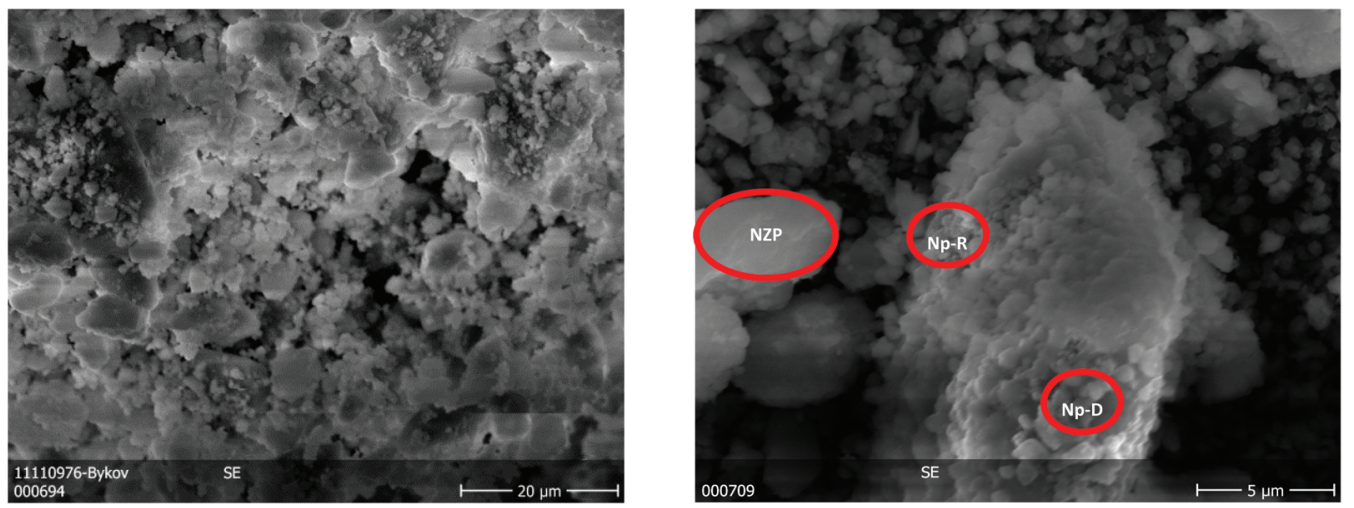

Fig. 7 Microstructure of the Np-sample obtained by SEM (secondary electrons). EDX analysis shows three phases: (1) NZP, the composition of which oscillates around the expected Np : Zr ratio in the targeted material; (2) Np-R, a neptunium-rich region; and (3) Np-D - a neptunium depleted region. 
Table 4 Unit cell parameters of the neptunium sample (sp. gr. $P \overline{3} c$ ) heated in argon and cooled to room temperature

\begin{tabular}{llll}
\hline Temperature, ${ }^{\circ} \mathrm{C}$ & $a, \AA$ & $c, \AA$ & $V, \AA^{3}$ \\
\hline 800 & $8.756(1)$ & $23.100(3)$ & 1534 \\
856 & $8.750(3)$ & $23.072(9)$ & 1530 \\
900 & $8.735(4)$ & $23.029(2)$ & 1522 \\
1000 & $8.695(1)$ & $22.952(5)$ & 1503
\end{tabular}

treatment, leading to the contraction of the unit cell. At the same time, the relative change of the cell parameters is small and does not exceed $0.7 \%$ for both $a$ and $c$.

The phenomenon of contraction upon heating for the NZP structure is rare but known. For example, the temperature behaviour of the erbium-zirconium phosphate $\mathrm{Er}_{0.33} \mathrm{Zr}_{2}\left(\mathrm{PO}_{4}\right)_{3}$ was investigated by Orlova et $a .^{43}$ It was found that despite expansion and contraction along different crystallographic directions upon heating, contraction of the structure as a whole takes place. In this case, the contribution of the axial negative and relatively large in absolute value coefficients $\alpha_{a}$ and $\alpha_{b}$, compared to the positive coefficient $\alpha_{c}$, is responsible for the negative average value of $\alpha_{a v}$.

With regard to the studied compound, two possibilities should be considered as an explanation:

1. Temperature hysteresis, as observed for the phosphate $\mathrm{Zr}_{0.25} \mathrm{Zr}_{2}\left(\mathrm{PO}_{4}\right)_{3} \cdot{ }^{31}$ The unit cell parameters of the sample at room temperature obtained after the heating cycle from 25 to $575{ }^{\circ} \mathrm{C}$ were somewhat smaller compared to the initial values (less than $0.35 \%$ ). Moreover, for this compound a secondorder phase transition upon heating was found, which was accompanied by the contraction of the structure along all crystallographic directions.

2. There is a possibility that an oxidation process with the formation of the oxidation state +4 of neptunium occurs during heating. Since the ionic radius of $\mathrm{Np}^{4+}$ is smaller than $\mathrm{Np}^{3+}$ in hexahedral coordination $(0.87 \AA$ vs. $1.01 \AA$, respectively), partial oxidation of $\mathrm{Np}^{3+}$ to $\mathrm{Np}^{4+}$ would also lead to the contraction of the crystal lattice.

From the data that we have obtained it is not possible to conclude which option would be the most likely.

In the case of samples heated above $800{ }^{\circ} \mathrm{C}$ in oxygen the indexing of the diffraction patterns was more difficult due to the increasing complexity of the diffractograms with increasing temperature. Therefore, the unit cell parameters were not calculated. However, after removing from consideration the peaks belonging to the $\mathrm{ZrP}_{2} \mathrm{O}_{7}$ phase, the remaining reflections might indicate the appearance of a superstructure $\left(805{ }^{\circ} \mathrm{C}\right)$ and partial decomposition of the sample $\left(900^{\circ} \mathrm{C}\right)$.

\section{Concluding remarks}

Based on the analysis of the literature data carried out by Bykov, ${ }^{15}$ the phosphates $\mathrm{M}_{x} \mathrm{Zr}_{2}\left(\mathrm{PO}_{4}\right)_{3}(\mathrm{M}$ - mono-, di-, tri- and tetravalent cations) crystallize in two structure types: $\mathrm{NaZr}_{2}\left(\mathrm{PO}_{4}\right)_{3}$ for the cations with radii from 0.71 to $1.67 \AA$ and the structure of scandium tungstate $\mathrm{Sc}_{2}\left(\mathrm{WO}_{4}\right)_{3}(\mathrm{SW})$ for the cations with radii 0.49-0.66 А. Both structures are composed of the same basic framework units $\left[\mathrm{Zr}_{2}\left(\mathrm{PO}_{4}\right)_{3}\right]^{-}$, but differ in the arrangement of these units and the coordination number of an interstitial cation $(\mathrm{CN}=4$ for $\mathrm{SW}){ }^{44}$ The radii of both $\mathrm{Np}^{3+}$ and $\mathrm{Np}^{4+}$ in octahedral coordination fall within the first range (1.01 and $0.87 \AA$, respectively).

The existence of a solid solution $\mathrm{NaZr}_{2-x} \mathrm{~Np}_{x}\left(\mathrm{PO}_{4}\right)_{3}(0 \leq x \leq$ $0.6)$, similar to solid solutions $\mathrm{Na}_{1+x} \mathrm{R}_{x} \mathrm{Zr}_{2-x}\left(\mathrm{PO}_{4}\right)_{3}(\mathrm{R}=\mathrm{In}, \mathrm{Yb}$, Er, Y, Dy, Tb, Gd, Sm, $0 \leq x \leq 1),{ }^{25}$ suggests that both tri- and tetravalent neptunium cations can substitute zirconium in the $\mathrm{ZrO}_{6}$ framework. However, the analogy of the XRD and IR spectra obtained in the present work with those for the $\mathrm{Ln}_{0.33} \mathrm{Zr}_{2}\left(\mathrm{PO}_{4}\right)_{3}$ phosphates, as well as the relatively low synthesis temperature, leads to the conclusion that the Np atoms occupy the interstitial M1 sites. At the same time, the results of Mössbauer spectroscopy show the presence of a mixture of two Np-containing hexagonal phases and an $\mathrm{NpO}_{2}$ admixture. Since no other crystalline phases containing neptunium were revealed from the XRD pattern during Rietveld analysis (including the fact that $\mathrm{NpO}_{2}$ was identified from the pattern), and also because it is unlikely that $\mathrm{Np}$ is present in an amorphous phase, it is assumed that the secondary Np-containing phase belongs to the same structure type, where $\mathrm{Np}^{4+}$ occupies similar but not the same crystallographic positions. It can also be concluded that in the absence of a charge compensator of lower valence it is harder for bigger neptunium cations to compete with the smaller zirconium ones for the occupation of framework positions. This conclusion is further strengthened by the fact that the unit cell parameters of the new neptunium phase correlate well with the data for the lanthanide phosphates ${ }^{16}$ as shown in Fig. 9. The mean neptunium radius shown on this picture is calculated based on the atomic percentages of $\mathrm{Np}^{3+}$ and $\mathrm{Np}^{4+}$ found in the present work.

Designing crystalline waste forms generally requires detailed crystal chemical knowledge of the site preferences of the waste ions and adjustment of the overall stoichiometry when producing the final product. The results of the present paper illustrate crystal chemical flexibility of the NZP phases, which to some extent allows for variations in stoichiometry, and the ability to incorporate elements with complex redox behaviour, such as the actinide elements. The additional formation of the $\mathrm{ZrP}_{2} \mathrm{O}_{7}$ phase, observed as an impurity in this study, can be an advantage when it comes to waste applications. This phase does not contain actinides and can play the role of a chemical buffer during the synthesis of a waste material, so that variations of chemical composition would cause a change in the ratios of the phases present and not the nature of these phases.

In conclusion, the new phosphate with an empirical formula $\mathrm{Np}_{0.29} \mathrm{Zr}_{2}\left(\mathrm{PO}_{4}\right)_{3}$ complements the series of NZP compounds with actinide and lanthanide atoms in the interstitials positions of the structure. The results of the present study show that the possibility of coexistence of several oxidation states in compounds of neighbouring elements $\mathrm{U}$ and $\mathrm{Pu}$ needs to be taken into account. 

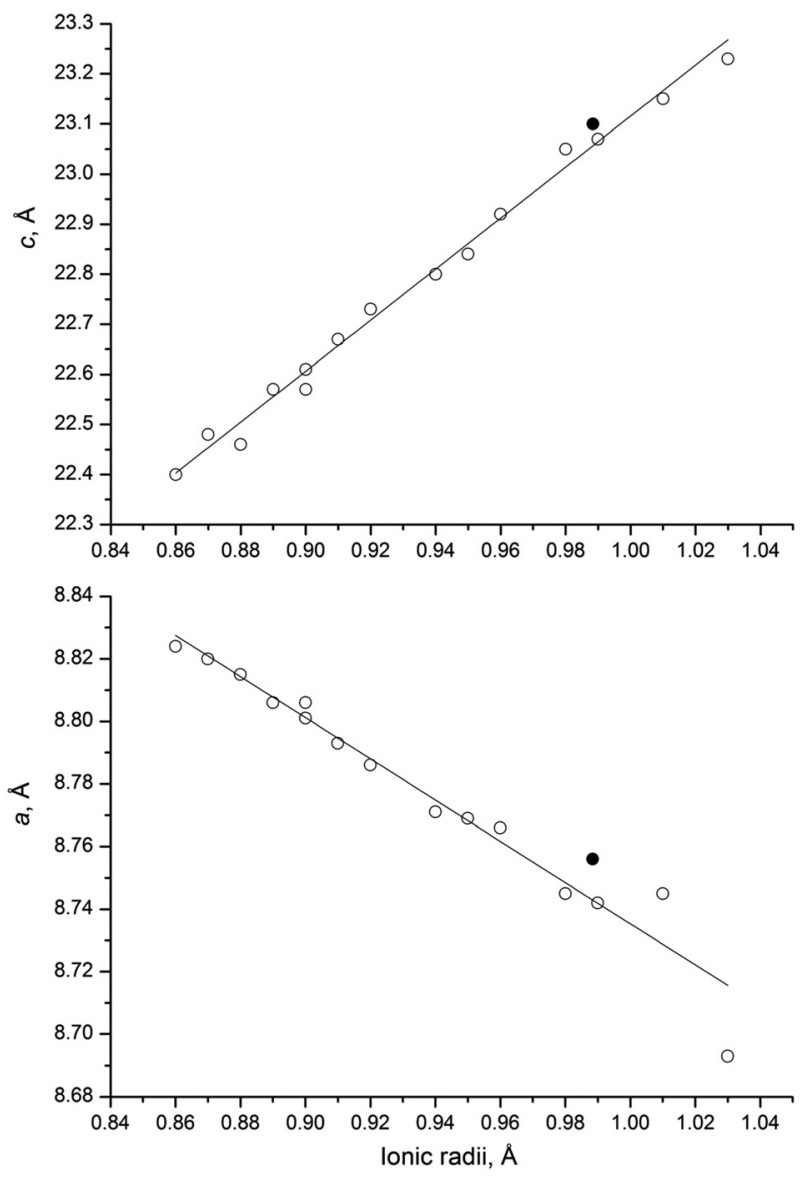

Fig. 9 Comparison of the unit cell parameters $a$ and $c$ of neptunium zirconium phosphate $(\bullet)$ with the trend reported in the paper by Bykov et al. ${ }^{16}$ for $\mathrm{Ln}_{0.33} \mathrm{Zr}_{2}\left(\mathrm{PO}_{4}\right)_{3}(\mathrm{O}): \mathrm{Ln}=\mathrm{La}, \mathrm{Ce}, \mathrm{Pr}, \mathrm{Nd}, \mathrm{Sm}, \mathrm{Eu}, \mathrm{Gd}, \mathrm{Tb}, \mathrm{Dy}$, $\mathrm{Ho}, \mathrm{Y}, \mathrm{Er}, \mathrm{Tm}, \mathrm{Yb}$ and $\mathrm{Lu}$. The ionic radius of neptunium shown in this graph corresponds to the average value between $\mathrm{Np}^{3+}$ and $\mathrm{Np}^{4+}(\mathrm{CN}=6)$ based on the molar percentages found by Mössbauer spectroscopy.

\section{Conflicts of interest}

There are no conflicts to declare.

\section{Acknowledgements}

The authors would like to thank V. S. Kurazhkovskaya for the discussion on the IR spectra. D.B. acknowledges the European Commission and the Deutscher Akademischer Austauschdienst, DAAD, for the fellowship fundings.

\section{References}

1 A. I. Orlova, Radiochemistry, 2002, 44, 423.

2 A. I. Orlova, V. N. Zyryanov, A. R. Kotel'nikov, V. T. Demarin and E. V. Rakitina, Radiochemistry, 1993, 35, 717.

3 A. I. Orlova, V. N. Zyryanov, O. V. Egor'kova and V. T. Demarin, Radiochemistry, 1996, 38, 20.
4 A. I. Kryukova, I. A. Kulikov, G. Yu. Artem'eva, O. V. Pechenevskaya and V. A. Alferov, Radiokhimiya, 1992, 34, 82 .

5 A. I. Orlova, Yu. F. Volkov, R. F. Melkaya, L. Yu. Masterova, I. A. Kulikov and V. A. Alferov, Radiochemistry, 1994, 36, 322.

6 T. Oota and I. Yamai, J. Am. Ceram. Soc., 1986, 69, 1.

7 M. Alami Talbi, R. Brochu, C. Parent, L. Rabardel and G. Le Flem, J. Solid State Chem., 1994, 110, 350.

8 M. Hirayama, N. Sonoyama, A. Yamada and R. Kanno, J. Solid State Chem., 2009, 182, 730.

9 B. Glorieux, V. Jubera, A. I. Orlova, A. E. Kanunov, A. Garcia, C. Pallier and T. A. Oleneva, Inorg. Mater., 2013, 49, 82.

10 A. I. Orlova, A. E. Kanunov, E. N. Gorshkova, A. N. Shushunov, S. N. Pleskova, E. R. Mikheeva, D. O. Savinykh and E. S. Leonov, Inorg. Mater., 2013, 49, 89.

11 Y. Miyajima, Y. Saito, M. Matsuoka and Y. Yamamoto, Solid State Ionics, 1996, 84, 61.

12 K. Nomura, S. Ikeda, K. Ito and H. Einaga, Bull. Chem. Soc. Jpn., 1992, 65, 3221.

13 D. M. Bykov, G. Sh. Shekhtman, A. I. Orlova, V. S. Kurazhkovskaya, E. Yu. Borovikova and V. Yu. Volgutov, Solid State Ionics, 2011, 182, 47.

14 L.-O. Hagman and P. Kierkegaard, Acta Chem. Scand., 1968, 22, 1822.

15 D. M. Bykov, PhD thesis, Nizhny Novgorod State University, 2006.

16 D. M. Bykov, E. R. Gobechiya, Yu. K. Kabalov, A. I. Orlova and S. V. Tomilin, J. Solid State Chem., 2006, 179, 3101.

17 M. Barre, M. P. Crosnier-Lopez, F. Le Berre, J. Emery, E. Suard and J.-L. Fourquet, Chem. Mater., 2005, 17, 6605.

18 H. T. Hawkins, D. R. Spearing, D. K. Veirs, J. A. Danis, D. M. Smith, C. D. Tait, W. H. Runde, M. N. Spilde and B. E. Scheetz, Chem. Mater., 1999, 11, 2851.

19 A. I. Orlova, in Structural Chemistry of Inorganic Actinide Compounds, ed. S. V. Krivovichev, P. C. Burns and I. G. Tananaev, Elsevier, Amsterdam, 2007, ch. 8, pp. 315-339.

20 A. I. Orlova, A. A. Charlamova and Yu. F. Volkov, in Review of Excess Weapons Plutonium Disposition LLNL Contract Work in Russia, ed. L. J. Jardine and G. B. Borisov, Lawrence Livermore National Laboratory, Livermore, 2002, pp. 407-418.

21 H. T. Hawkins, D. R. Spearing, D. M. Smith, F. G. Hampel, D. K. Veirs and B. E. Scheetz, in AIP Conf. Proc, 2000, vol. 532, p. 168.

22 Yu. F. Volkov, R. F. Melkaya, V. I. Spiryakov and G. A. Timofeev, Radiokhimiya, 1994, 36, 205.

23 Yu. F. Volkov, S. V. Tomilin, A. I. Orlova, A. A. Lizin, V. I. Spiryakov and A. N. Lukinykh, Radiochemistry, 2003, 45, 319 .

24 A. A. Burnaeva, Yu. F. Volkov, A. I. Kryukova, I. A. Korshunov and O. V. Skiba, Radiokhimiya, 1992, 34, 12.

25 Y. Miyajima, T. Miyoshi, J. Tamaki, M. Matsuoka, Y. Yamamoto, C. Masquelier, M. Tabuchi, Y. Saito and H. Kageyama, Solid State Ionics, 1999, 124, 201. 
26 D. M. Bykov, A. I. Orlova, S. V. Tomilin, A. A. Lizin and A. N. Lukinykh, Radiochemistry, 2006, 48, 234.

27 V. S. Kurazhkovskaya, D. M. Bykov and A. I. Orlova, J. Struct. Chem., 2004, 45, 966.

28 A. I. Orlova, V. Yu. Volgutov, G. R. Castro, S. García-Granda, S. A. Khainakov and J. R. García, Inorg. Chem., 2009, 48, 9046.

29 J. Alamo and R. Roy, J. Am. Ceram. Soc., 1984, 67, C-80.

30 A. E. Mel'nikov and I. A. Bondar', Russ. J. Inorg. Chem., 1989, 34, 2122.

31 A. I. Orlova, S. G. Samoilov, G. N. Kazantsev, V. Yu. Volgutov, D. M. Bykov, A. V. Golubev and E. Yu. Borovikova, Crystallogr. Rep., 2009, 54, 431.

32 S. Cotton, in Lanthanide and Actinide Chemistry, Wiley, Chichester, West Sussex, UK, 2006.

33 B. E. Burakov, M. I. Ojovan and W. E. Lee, Crystalline Materials for Actinide Immobilisation, Imperial College Press, London, 2010.

34 J. Rodríguez-Carvajal, Commission on Powder Diffraction (IUCr), Newsletter, 2001, 26, 12.

35 K. Momma and F. Izumi, J. Appl. Crystallogr., 2008, 41, 653.
36 J. L. Pouchou and F. Pichoir, in Electron Probe Quantitation, ed. K. F. J. Heinrich and D. E. Newbury, Plenum Press, New York, 1991, pp. 31-76.

37 V. S. Kurazhkovskaya, D. M. Bykov, E. Yu. Borovikova, N. Yu. Boldyrev, L. Mikhalitsyn and A. I. Orlova, Vib. Spectrosc., 2010, 52, 137.

38 P. Tarte, A. Rulmont and C. Merckaert-Ansay, Spectrochim. Acta, Part A, 1986, 42, 1009.

39 D. M. C. Huminicki and F. C. Hawthorne, Rev. Mineral. Geochem., 2002, 48, 123.

40 D. M. Bykov, R. J. M. Konings and A. I. Orlova, J. Alloys Compd., 2007, 439, 376.

41 S. Tamura, N. Imanaka and G. Adachi, Solid State Ionics, 2002, 154-155, 767.

42 J. M. Heintz, L. Rabardel, M. Al Qaraoui, M. Alami Talbi, R. Brochu and G. Le Flem, J. Alloys Compd., 1997, 250, 515.

43 A. I. Orlova, S. G. Samoilov, G. N. Kazantsev, V. Yu. Volgutov and A. Yu. Kazakova, Radiochemistry, 2010, 52, 666 .

44 Y. Piffard, A. Verbaere and M. Kinoshita, J. Solid State Chem., 1987, 71, 121. 